\title{
Effect of age and height position on physical and mechanical properties of rubber wood (hevea brasiliensis) of bangladesh
}

\author{
M. S. M. Majumdar ${ }^{1}$, A. K. Das ${ }^{* 2}$, M. I. Shams ${ }^{1}$ and M. Q. Chowdhury ${ }^{3}$ \\ ${ }^{1}$ Forestry and Wood Technology Discipline, Khulna University, Khulna-9208, Bangladesh. \\ ${ }^{2}$ Pulp and Paper Technology, Asian Institute of Technology, Thailand. \\ ${ }^{3}$ Department of Forestry and Environmental Sciences, Shahjalal University of Science and Technology, \\ Sylhet-3114, Bangladesh.
}

\begin{abstract}
The physical and mechanical properties of rubber (Hevea brasiliensis) wood of Bangladesh of 20, 25 and 30-year age groups were studied. The moisture content of rubber wood was $63 \%$ and volumetric shrinkage was $7.43 \%$. The green density and air-dry (12\% moisture content) density of rubber wood from 30 years age class was 570 and 590 1.c. $/ \mathrm{m}^{3}$. Significant difference in moisture content, shrinkage and density was found among the different age classes and height positions. However, longitudinal shrinkage did not vary among the age classes. The MOE and MOR values (air dried) of rubber wood from 30 years age class was 9200 and $65.33 \mathrm{MPa}$. In most conditions, significant difference with age class and height positions was observed for mechanical properties. The maximum values were found at the bottom position of 30 years age group. On the other hand, the lowest values were observed in the top position of 20 years age group. The strength properties were lower than teak (Tectona grandis), but some strength properties were higher than mahogany (Switenia macrophylla).
\end{abstract}

Keywords: Physical properties; Mechanical properties; MOR (Modulus of rupture); MOE (Modulus of elasticity); Hevea brasiliensis

\section{Introduction}

Rubber (Hevea brasiliensis Müll. Arg.) is predominately distributed in tropical and sub tropical regions. In Bangladesh it was introduced in 1956 and has been planted for rubber tapping (Sattar et al., 1992). It is a fast growing deciduous tree, rarely exceeding $25 \mathrm{~m}$ height in plantations while wild rubber trees sometimes exceed $40 \mathrm{~m}$. Bark is whitish or greenish brown when young; becomes rough, blackish and cracked when old. The inner bark produces white latex, which is the source of commercial rubber. Available log volume for diameters above $15 \mathrm{~cm}$ ranges from $52 \mathrm{~m}^{3} \mathrm{ha}^{-1}$ to $162 \mathrm{~m}^{3} \mathrm{ha}^{-1}$. The utilizable wood volume per hectare depends upon numerous factors such as clone, site and management. Sawn timber recovery lies between 25 and 45 percent (Wong and Ong, 1979). It is light yellowish white on fresh cut, but turned into brown on exposure. The sapwood and heartwood are indistinguishable by color. Wood texture is moderately coarse to even. It has straight to shallowly interlocked grain with attractive figures in the longitudinal surface (Mohiuddin, 1993), which increases the decorative value of the rubber wood.

It is suitable for the manufacture of furniture and cabinet making because of its medium density and strength, good woodworking and finishing qualities, appealing grain texture, color (Hannan and Khaleque, 1992).
The latex production reduces after 20-year and within 22 to 29-year age latex production becomes uneconomic (Anon., 2002). Trees are then clear felled and the area is replanted. Timber from these trees is a by-product from rubber plantation in Bangladesh. Rubber wood is used an alternative timber species for different end-uses, i. e., furniture, parquet, paneling, flooring, wood based panels and indoor building components (Killmann and Hong, 2000). Information regarding physical and mechanical properties is required for better utilization of wood (Chowdhury et al., 2005). These properties are not same for the same tree from top to the bottom. Tree age also affects wood properties (Chowdhury et al., 2005; Mitchell and Denne, 1997). Thus it is imperative to get information about the effect of age and height on the properties of rubber wood for its proper uses. To this end, the study on the effect of age and height position on the physical and mechanical properties of rubber wood is important.

\section{Materials and methods}

Samples are collected from the Raozan Rubber Garden in Chittagong in Bangladesh. The soil of the area is sandy to sandy clay loam, and the area has a moist tropical climate characterized by a period of high precipitation from April to 
September and a comparatively dry period from November to March. With minor variations, relative humidity remains high at $70-95 \%$ (average $85 \%$ ) throughout the year (Anon., 2002).

All the trees were fairly straight and free from natural defects. Each of the trees of 25 and 30 years age class had reached the girth of at least $65 \mathrm{~cm}$. For 20 year trees, recently wind uprooted tree was selected, because in 20 years rubber production is in full swing, and collection of samples from a 20 -year age class tree is hard nut to crack.

After felling, each bole was cut, if possible into $2.5 \mathrm{~m} \mathrm{logs}$ (butt, middle and top). In the age class of 20 years, the total length of the tree was only $7.0 \mathrm{~m}$ and the top position was consequently shorter. Details of the total log length and mean mid-diameter of the three logs in each age class are given in Table I.

Rubber wood is much biodegradable. So immediately after harvesting and sawing, there was sprayed sodium pentachloride preservative. The bolts were cut at first with 36 -inch band saw and then it was made to smaller pieces of $6.3 \mathrm{~cm}$ in thickness and $6.3 \mathrm{~cm}$ in width by using 32-inch band saw. The length of planks was fixed into 4 feet by the help of cross cut saw.

Table I. Characteristics of logs from sample trees of Hevea brasiliensis.

\begin{tabular}{lrrc}
\hline \multirow{2}{*}{ Log dimensions } & \multicolumn{3}{c}{ Age class (years) } \\
\cline { 2 - 4 } & 20 & 25 & 30 \\
\hline Mean total length in tree (m) & 7.0 & 7.4 & 7.55 \\
Mean mid point diameter $(\mathrm{cm})$ & 12.0 & 15.2 & 19.5 \\
\hline
\end{tabular}

Three trees of 20, 25 and 30 year age groups were selected and samples were collected from bottom, middle and top of the tree. The specimens for determination of moisture content, density and shrinkage were in the form of $5.08 \mathrm{~cm} \times$ $5.08 \mathrm{~cm} \times 2.54 \mathrm{~cm}$. Moisture content was measured in oven dry method. Shrinkage in three linear directions was evaluated as percentages of dimensional changes from green condition to oven dry condition on drying for $24 \mathrm{~h}$ to a constant weight at a temperature of $103^{\circ} \mathrm{C} \pm 2^{\circ} \mathrm{C}$. The dimensions were measured both in green and oven dry condition with a slide caliper, and weight was taken on an electric balance to an accuracy of $0.01 \mathrm{~g}$. Basic density was determined by water displacement method.

The specimen for compression test was in the form of $7.5 \mathrm{~cm}$ $\times 2.5 \mathrm{~cm} \times 2.5 \mathrm{~cm}$. Compression tests were undertaken both for perpendicular and parallel to the grain. For the tension study cylindrical specimens of $1 \mathrm{~cm}$ diameter was taken. The gauge length and diameter were $5.5 \mathrm{~cm}$ and $1 \mathrm{~cm}$ respectively and the length of the grips was $6 \mathrm{~cm}$ at each end. The specifications for bending test were in the form of $50 \mathrm{~cm} \times 5$ $\mathrm{cm} \times 2.5 \mathrm{~cm}$. Mechanical properties were evaluated in accordance with the specification of ASTM (Anon., 1971).

Modulus of Elasticity (MOE) was calculated from the following equation-

$M O E=\frac{P^{/} L^{3}}{4 \Delta^{\prime} b d^{3}}$

Where, $\mathrm{MOE}=$ is the modulus of elasticity in bending, in $\mathrm{N} / \mathrm{mm}^{2}, \mathrm{P}^{\prime}=$ is the load, in $\mathrm{N}$ at the limit of proportionality, $\mathrm{L}=$ is the span, in $\mathrm{mm}, \Delta^{\prime}=$ is the deflection, in $\mathrm{mm}$ at the limit of proportionality, $\mathrm{b}=$ is the width, in $\mathrm{mm}, \mathrm{d}=$ is the depth, in $\mathrm{mm}$.

The modulus of Rupture (MOR) was calculated from the following equation- (Desch and Dinwoodie, 1996).

$M O R=\frac{3 P L}{2 b d^{2}}$

Where, $\mathrm{MOR}=$ modulus of rupture, in $\mathrm{N} / \mathrm{mm}^{2}, \mathrm{P}=$ is the load, in $\mathrm{N}, \mathrm{L}=$ is the span, in $\mathrm{mm}, \mathrm{b}=$ is the width, in $\mathrm{mm}, \mathrm{d}=$ is the depth, in $\mathrm{mm}$

ANOVA (F-test) was employed to determine the effects of age and height on physical as well on mechanical properties.

\section{Results and discussion}

The moisture content of different height position for 20,25 and 30 years tree is presented in Table 2. The moisture content decreased from top to bottom gradually in every age group of the tree. In this study, it was found that the moisture content was the highest for 20 years old tree and lowest for 30 years tree.

The amount of water in wood affects weight, permeability, dimensional stability and strength. Thus the quality wood products are affected by water. Water in green or freshly harvested wood is located in cell wall and cell lumen (Haygreen and Bowyer, 1982). When the wood is dried to oven-dry condition, all the liquid water in cell lumen is removed, though there always remains some water vapor. The amount of shrinkage is affected by the amount of moisture lost by wood when its moisture content fluctuates between the oven dry state and fiber saturation point. The relationship is linear and applied in tangential, radial and 
longitudinal directions, and therefore to volumetric changes (Tsoumis, 1991). Radial, tangential and longitudinal shrinkage of different height position for 20, 25 and 30 years tree are shown in Table II. Tangential shrinkage was the highest at every height position for every age group. Shrinkage at tangential and radial directions was lower at the bottom position of 30 years tree than other two trees but longitudinal shrinkage was lower for top portion of 20 years tree than other two trees. Sattar (1997) observed that the radial, tangential and volumetric shrinkage was $1.99,4.95$ and $8.35 \%$ for rubber wood. Indian rubber wood shows the longitudinal shrinkage ranges from 0.10 to $0.19 \%$, radial shrinkage ranges from 2.6 to $3.1 \%$, tangential shrinkage ranges from 5.7 to $6.5 \%$ and the volumetric shrinkage ranges from 10.1 to $12 \%$ (Anon., 2002). The top position had shown the most shrinkage in all age from about 0.10 to $0.30 \%$ (Anon., 1970). Kollman and Côté (1984) explained that shrinkage differs in tangential and radial directions due to the restraining effects of fibril angle in the cell walls, while Schniewind (1989) considered that the variation between shrinkage of different surfaces was due to cellular structure and physical organization of cellulose chain molecules within the cell walls.

Air-dry density ( $12 \%$ moisture content) of 20 years old tree was from 470 to $5101 . c . / \mathrm{m}^{3}, 25$ years from 500 to 560 1.c. $/ \mathrm{m}^{3}$ and 30 years from 530 to $6401 . c . / \mathrm{m}^{3}$ (Table 2). The density was higher at the bottom and lower at the top for the tree of every age group. Desch and Dinwoodie (1996) stated that the density decreased gradually from bottom to top. Rubber wood is a medium dense timber with average density 510 to

Table II. Physical properties of Hevea brasiliensis of different height position.

\begin{tabular}{lcccccc}
\hline Age group & Position & $\begin{array}{c}\text { Moisture Content } \\
(\%)\end{array}$ & $\begin{array}{c}\text { Density } \\
\mathrm{kg} / \mathrm{m}^{3}\end{array}$ & \multicolumn{3}{c}{$\begin{array}{c}\text { Shrinkage value } \\
(\%)\end{array}$} \\
\cline { 3 - 7 } 20 years & Top & 69.2 & 470 & 6.10 & 3.20 & 0.12 \\
& Middle & 68.3 & 470 & 5.60 & 2.92 & 0.15 \\
& Bottom & 66.4 & 510 & 4.32 & 2.24 & 0.13 \\
\hline \multirow{2}{*}{25 years } & Top & 60.1 & 500 & 5.03 & 2.56 & 0.13 \\
& Middle & 61.1 & 540 & 4.91 & 2.11 & 0.14 \\
& Bottom & 65.1 & 560 & 4.15 & 2.10 & 0.18 \\
\hline 30 years & Top & 61.0 & 530 & 4.92 & 2.40 & 0.17 \\
& Middle & 58.4 & 590 & 4.60 & 2.10 & 0.17 \\
& Bottom & 55.7 & 640 & 4.02 & 2.03 & 0.18 \\
\hline
\end{tabular}

groups. The shrinkage value was observed highest in the top position of 20 years age class and lowest in bottom position of a 30 years age class rubber tree, due to presence of highest and lowest values of moisture content. The observations of this study also indicate that the tangential shrinkage is about two times higher than the radial shrinkage in rubber wood and the longitudinal shrinkage ranged from 0.10 to $0.15 \%$. Panshin and de Zeeuw (1980) stated that tangential shrinkage is about twice as more as the radial shrinkage. The longitudinal shrinkage of wood is negligible for practical purposes, ranging
540 1.c. $/ \mathrm{m}^{3}$ depending on green volume and air-dried volumes (Sattar et al., 1992). The average basic density of Malaysian rubber wood ranges from 460 to $6501 . c . / \mathrm{m}^{3}$ (Lee, 1982) and Indian rubber wood is 520 1.c. $/ \mathrm{m}^{3}$ (Anon., 2002).

In the study for physical properties, significant difference was found for all physical properties among different age class and in three height positions, except radial shrinkage in different height position and longitudinal shrinkage over different age class as shown in Table III. 
Table III. Summery for ANOVA test of physical properties.

\begin{tabular}{lcccc}
\hline Source of variation & MC & & Shrinkage & Longitudinal \\
& & Tangential & Radial & AD \\
Height & $*$ & $*$ & $*$ & $*$ \\
\hline
\end{tabular}

*Note: *= Significant and ns= Not significant at $95 \%$ probability level

The MOE for 20 years old tree varied from 8239 to 8512 $\mathrm{MPa}, 25$ years from 8697 to $8973 \mathrm{MPa}$ and 30 years from 8887 to $9661 \mathrm{MPa}$ according to height position. The MOR in air-dried samples of 20 years old tree varied from 49.7 to 53.3 $\mathrm{MPa}, 25$ years from 46.3 to $48.7 \mathrm{MPa}$ and 30 years from 62.6
75.6 MPa (Anon., 2002). Density is considered as the most important factor affecting the strength of wood. The higher the density the higher the strength value (Desch and Dinwoodie, 1996).

Table IV. Mechanical properties of Hevea brasiliensis of different height position.

\begin{tabular}{|c|c|c|c|c|c|c|}
\hline Age group & Position & $\begin{array}{l}\mathrm{MOE} \\
(\mathrm{MPa})\end{array}$ & $\begin{array}{l}\text { MOR } \\
(\mathrm{MPa})\end{array}$ & $\begin{array}{l}\text { Compression } \\
\text { perpendicular } \\
\text { to grain }(\mathrm{MPa})\end{array}$ & $\begin{array}{l}\text { Compression } \\
\text { parallel } \\
\text { to grain }(\mathrm{MPa})\end{array}$ & $\begin{array}{c}\text { Tension } \\
\text { parallel } \\
\text { to grain }(\mathrm{MPa})\end{array}$ \\
\hline \multirow[t]{3}{*}{20 years } & Top & 8239 & 49.7 & 3.90 & 27.3 & 58.2 \\
\hline & Middle & 8239 & 52.8 & 3.95 & 28.7 & 58.9 \\
\hline & Bottom & 8512 & 53.3 & 4.01 & 30.0 & 59.3 \\
\hline \multirow[t]{3}{*}{25 years } & Top & 8697 & 46.3 & 4.27 & 29.9 & 65.9 \\
\hline & Middle & 8605 & 50.0 & 4.70 & 31.3 & 69.4 \\
\hline & Bottom & 8973 & 48.7 & 5.06 & 31.4 & 72.4 \\
\hline \multirow[t]{3}{*}{30 years } & Top & 8887 & 62.6 & 4.62 & 31.1 & 75.4 \\
\hline & Middle & 9020 & 65.5 & 4.89 & 31.8 & 84.0 \\
\hline & Bottom & 9661 & 67.8 & 5.30 & 32.6 & 92.1 \\
\hline
\end{tabular}

to $67.8 \mathrm{MPa}$ (Table IV). Malaysian rubber wood showed the values of MOE and MOR around 9.25 GPa and 66 MPa (Lee, 1982) and Indian rubber wood (air-dry) was $8.20 \mathrm{GPa}$ and
The compression perpendicular to grain at air dry condition of 20 years old tree varied from 3.90 to $4.01 \mathrm{MPa}, 25$ years from 4.27 to $5.06 \mathrm{MPa}$ and 30 years from 4.62 to $5.30 \mathrm{MPa}$. 
The compression parallel to grain at air dry condition of 20 years old tree varied from 27.3 to $30.0 \mathrm{MPa}, 25$ years from 29.9 to $31.4 \mathrm{MPa}$ and 30 years from 31.1 to $32.6 \mathrm{MPa}$. The tension parallel to grain at air dry condition for 20 years old tree varied from 58.2 to $59.3 \mathrm{MPa}, 25$ years from 65.9 to 72.4 MPa and 30 years from 75.4 to $92.1 \mathrm{MPa}$ (Table IV).

There was a significant difference in MOE, compression perpendicular to grain and compression parallel to grain among different ages and height positions of rubber tree (Table IV). For MOR and tension parallel to grain, there was no significant difference among different age classes, but in the aspect of height position, there was significant difference (Table V).

Table V. Summery of ANOVA test of mechanical properties

\begin{tabular}{lllcc}
\hline $\begin{array}{l}\text { Source of } \\
\text { variation }\end{array}$ & $\begin{array}{l}\text { MOE } \\
(\mathrm{MPa})\end{array}$ & $\begin{array}{c}\mathrm{MOR} \\
(\mathrm{MPa})\end{array}$ & $\begin{array}{c}\text { Compression } \\
\text { perpendicular } \\
\text { to grain (MPa) }\end{array}$ & $\begin{array}{c}\text { Compression } \\
\text { parallel to grain }(\mathrm{MPa})\end{array}$ \\
\hline Age & $*$ & $\mathrm{~ns}$ & $*$ & $*$ \\
Height & $*$ & $*$ & $*$
\end{tabular}

Note: $*=$ Significant and $\mathrm{ns}=$ Not significant at $95 \%$ probability level.

The rubber production reduces from 20 years. At the age of 22 to 29 years, latex production becomes uneconomic (Anon., 2002). Trees of 30 years age class, which had already lost its capability to produce latex, showed highest values of all the physical and mechanical properties. The 25 years tree also had shown good physical and mechanical values because the production of latex turns lower in that age. The physical and mechanical properties were the lowest in the 20 year aged tree.

In Bangladesh, the strength properties of teak (Tectona grandis) of 40 year age is used as a standard to which all other timber species of the Country may be compared to determine their relative suitability for various purposes (Yakub et al., 1978). Compared to teak (Yakub et al., 1978), the moisture content and shrinkage are higher, but density lower than teak (relative to teak, moisture content is $106.1 \%$, volumetric shrinkage $139.4 \%$, basic density $98.3 \%$ and air dry density $96.7 \%$ ) with rubber wood. In case of mechanical properties, the properties are lower than teak (relative to teak, air-dry MOE $70.2 \%$, air-dry MOR $64.8 \%$, air-dry compression parallel to grain $62.0 \%$ and air-dry compression perpendicular to grain $41.5 \%$ ). In comparison with mahogani (Switenia macrophylla) (Sattar, 1997), rubber wood shows higher density and air-dry MOR. But air-dry MOE is slight lower (relative to mahogany, density is $113.5 \%$, air dry MOR is $109.4 \%$ and air dry MOE is $92 \%$ ). Because of good physical and mechanical properties rubber wood attaining 30 years can be a good raw material in wood industry.

\section{Conclusion}

There was significant difference in most physical properties due to age and height difference of rubber wood. The moisture content and shrinkage was the highest in 20-year age group, while the lowest in 30-year age class. The highest density is observed in 30-year age group in air-dry condition. All strength properties showed significant difference over height position and age class in most observations. Compared with teak, the physical and mechanical properties are slightly low. On the other hand, the properties are similar to mahogany. Therefore, there is a great opportunity to use rubber wood in furniture making. This will reduce the pressure on conventional wood.

\section{References}

Anon. (2002). Integrated Forest Management Plan for Chittagong Forest Division. Bangladesh Forest Department, pp. 275-282.

Chowdhury, M. Q., Shams, M. I. and Alam, M. (2005). Effects of age and height variation on physical properties of mangium (Acacia mangium Willd.). wood Australian Forestry, 68(1): 17-19.

Desch, H. E. and Dinwoodie, J. M. (1996). Timber Structure, Properties, Conversion and Use. $7^{\text {th }}$ edition, Macmillan press Limited, London. pp.50-216.

Hannan, M. O. and Khaleque, M. A. (1992). Working and Finishing Properties of rubber (Hevea brasiliensis) Wood.Bulletin 7. Wood Working Series, Bangladesh Forest Research Institute, Chittagong, p.13.

Haygreen, J. G. and Bowyer J. L. (1992). Forest Products and Wood Science-An Introduction, Iowa, pp. 157-176. 
Killmann, W. and Hong, L. T. (2000). Rubber wood - the success of an agricultural by-product. Unasylva 51(2): 66-72.

Kollman, F. F. P. and Côté, W. A. (1984). Principles of Wood science and Technology, Volume I:Solid wood. Springer-Verlang, Berlin, Heidelberg, New York, Tokyo, pp.1-592.

Lee, Y. H. (1982). Malaysian timbers-rubber wood. Malaysian Forest Service Trade Leaflet No. 58. Kepong. Malaysia, Malaysian Timber Industry Board, p.9.

Mitchell, M. D. and Denne, M. P. (1997). Variation in density of Picea sitchensis in relation to within-tree trends in tracheid diameter andwall thickness. Forestry, 70: 51-62.

Mohiuddin, M. (1993). Anatomical studies of rubber wood (Hevea brasiliensis) from Bangladesh. Bangladesh Journal of Forest Science 22(1\&2): 57-60.

Panshin, A. J. and Zeeuw, C. d. (1980). Text Book of Wood Technology, $4^{\text {th }}$ ed. McGraw-Hill, New York, p.722.

Sattar M. A., Kabir, M. F., Bhattacharjee, D. K.; Sarker, S. B. (1992). Physical, Mechanical and Seasoning Properties of Bangladeshi Rubber Wood (Hevea brasiliensis). Bulletin 13. Timber Physics Series, Bangladesh Forest Research Institute, Chittagong. pp.4-8.
Sattar, M. A. (1997). Properties and uses of priority timber species. Bangladesh Journal of Forest Science,. 26(2): 1-7.

Schniewind, A. P. (1989). Concise Encyclopedia of Wood and Wood-based Materials. Pergamon Press, p.248.

Tsoumis, G. (1991). Science and Technology of Wood. Chapman and Hall, New York, p. 491.

Yakub, M; Ali, M. O. and Bhattacharjee, D. K. (1978). Strength properties of Chittagong teak (Tectona grandis) representating different age groups, Bull. 4 (Timber Physics Series), For. Res. Inst. Chittagong. p. 28.

Wong, W. C. and Ong, C. L. (1979). The Production Of Particleboard From Rubberwood. The Malaysian Forester 42:1.

Received: 5 June 2013; Revised: 25 March 2014

Accepted: 3 June 2014. 